\title{
Feedbacks between inundation, root production, and shoot growth in a rapidly submerging brackish marsh
}

\author{
Matthew L. Kirwan ${ }^{1 *}$ and Glenn R. Guntenspergen ${ }^{2}$ \\ ${ }^{1}$ Department of Environmental Science, University of Virginia, Charlottesville, VA 22904, USA; and ${ }^{2}$ Patuxent Wildlife \\ Research Center, US Geological Survey, Laurel, MD 20708, USA
}

\section{Summary}

1. Ecogeomorphic feedbacks between mineral sediment deposition and above-ground plant growth are thought to have dominated the evolution of many coastal ecosystems and landforms. However, land-use-related reductions in sediment delivery rates to estuaries world-wide suggest that these above-ground feedbacks may not apply in some of the world's most vulnerable coastal landscapes.

2. To understand the relationships between sea level rise and marsh survival, we measured root and shoot growth over experimentally manipulated elevations in a rapidly submerging, sediment deficient marsh.

3. Root growth was highest at a distinct optimum elevation in both Schoenoplectus americanus and Spartina patens. S. americanus shoot growth was highest at an optimum elevation, but $S$. patens shoot growth increased with elevation throughout the intertidal zone.

4. For marsh elevations that are higher than optimum (expected at low sea level rise rates), we propose that an acceleration in the rate of sea level rise will lead to enhanced root growth, organic accretion and wetland stability. For suboptimum marsh elevations (expected at rapid sea level rise rates and/or low sediment supply), increases in the water level will lead to reduced root growth and a decrease in the rate of elevation gain.

5. More than $80 \%$ of the marshland in our study area has an elevation below the optimum for root growth, suggesting that this previously unknown feedback could explain observations of rapid marsh deterioration in the region.

6. Synthesis. Below-ground responses of marshes to sea level rise are more broadly applicable than above-ground feedbacks because they are consistent among different species and do not depend on the availability of mineral sediment.

Key-words: accretion, climate change, peat, plant-climate interactions, productivity, sea level rise, wetland

\section{Introduction}

Despite recent observations of degradation, tidal wetlands have long been understood to be relatively resilient features of the coastal landscape because increases in rates of sea level rise tend to be accompanied by increases in vertical accretion (Redfield 1965; Allen 2000). Historical accretion rates are highest in regions with high relative sea level rise rates (Friedrichs \& Perry 2001; Cahoon et al. 2006), thick sequences of organic peat indicate that marshes commonly maintain an intertidal position for thousands of years (Redfield 1965), and numerical models predict wetland resiliency under sea level rise rates exceeding $10 \mathrm{~mm} \mathrm{year}^{-1}$ (Kirwan et al. 2010). Elucidating the mechanisms responsible for wetland adaptation and identifying their

*Correspondence author. E-mail: mlk4n@virginia.edu limits, however, remain an important challenge necessary to predict how wetlands will fare during 21 st century sea level rise.

Traditional explanations for the linkage between rates of sea level rise and marsh elevation change centre on interactions between above-ground plant growth and mineral sediment deposition. From a purely physical perspective, increased tidal inundation duration provides more time for sediment to settle out of the water column and onto the marsh surface, leading to faster mineral deposition rates (e.g. Marion, Anthony \& Trentesaux 2009). The growth of intertidal macrophytes is thought to enhance the strength of this feedback because the above-ground biomass of at least one species, Spartina alterniflora, is greatest during years of high sea level (Morris \& Haskins 1990). For moderate increases in inundation, enhanced above-ground biomass leads to faster settling velocities and mineral deposition rates (Mudd, 
D'Alpaos \& Morris 2010), resulting in marsh accretion rates that should increase with increasing sea level rise rates. Alternatively, at low elevations and/or fast rates of sea level rise, increases in inundation lead to reduced vegetation growth, lower deposition rates and rapid marsh submergence. Therefore, a parabolic or hump-shaped relationship between plant growth and inundation is thought to explain whether a marsh should be stable for thousands of years, or whether it will quickly submerge (Morris et al. 2002).

This conceptual framework between inundation, aboveground plant growth and mineral sediment deposition forms the basis of most numerical models of salt marsh evolution, as well as models of tidal channel network organization and delta growth (e.g. Mudd et al. 2004; D’Alpaos et al. 2006, 2007; Kirwan \& Murray 2007; Marani et al. 2007; Kirwan et al. 2010; Lorenzo-Trueba et al. 2010; Mariotti \& Fagherazzi 2010). However, several observations appear to limit its generality. First, the accumulation of below-ground organic matter is known to dominate the accretion process in many marshes (Nyman et al. 1993; Turner, Swenson \& Milan 2000; Cahoon et al. 2006; Nyman et al. 2006; Langley et al. 2009), and even marshes with little mineral sediment input commonly survive sea level rise for thousands of years (e.g. Redfield 1965). Secondly, a significant correlation between interannual sea level and above-ground biomass has been described for only one species in one estuary (Morris et al. 2002). Tight couplings between above-ground biomass and sea level variability are not widely evident in S. alterniflora marshes in Virginia (Kirwan et al. 2012), Massachusetts (Teal \& Howes 1996) or Louisiana (Visser, Sasser \& Cade 2006). Its application to species other than $S$. alterniflora remains untested, although observations of steadily increasing biomass with elevation in the Venice Lagoon suggest that a hump-shaped response may not apply when interactions between multiple species are considered (Marani et al. 2004). Finally, the proposed feedbacks have been described in a relatively stable salt marsh, characterized by regular tides and abundant sediment (Morris et al. 2002). In contrast, the wetlands most vulnerable to sea level rise are typically characterized by small tides, irregular fluctuations in water level and little mineral sediment (e.g. Reed 1995; Kirwan \& Guntenspergen 2010; Kirwan et al. 2010; Day et al. 2011).

Given world-wide declines in sediment delivery rates to coasts (Walling \& Fang 2003; Syvitsky et al. 2009) and observations of coastal change that are most rapid in sediment deficient regions (e.g. Mississippi River Delta, Venice Lagoon), an important question emerges: How do coastal ecosystems respond to sea level rise where sediment is not readily available? Although wetlands in some sediment deficient estuaries appear stable today (Plum Island Estuary, Kirwan et al. 2011), massive wetland loss in the Mississippi River Delta and Venice Lagoon (Day et al. 2011) indicates that there are limits to the conditions in which marshes can survive with little sediment. Here, we use a field-based mesocosm experiment to determine whether potential feedbacks between inundation, plant growth and vertical accretion exist in sediment deficient marshes, and to determine whether they can explain patterns of historical stability and recent rapid submergence.

\section{Materials and methods}

\section{SITE DESCRIPTION}

The experiments were conducted in a rapidly submerging marsh surrounding the Blackwater River, a large brackish estuary on the Eastern Shore of the Chesapeake Bay $\left(38.40^{\circ} \mathrm{N}, 76.07^{\circ} \mathrm{W}\right.$ ) (Maryland, USA). Variations in water level are primarily driven by meteorological events, with mean astronomical tides of $<15 \mathrm{~cm}$. Intertidal vegetation at the sites is dominated by mesohaline macrophytes Schoenoplectus americanus and Spartina patens. Spartina alterniflora and Phragmites australis are common in adjacent marshes where salinities are slightly higher or lower, respectively. Historical accretion rates in the area $\left(1.7-3.6 \mathrm{~mm} \mathrm{year}^{-1}\right)$ are less than the local rate of relative sea level rise $\left(3.9 \mathrm{~mm} \mathrm{year}^{-1}\right)$, resulting in widespread ponding and loss of marsh vegetation (Stevenson, Kearney \& Pendleton 1985). More than 2000 ha of marshland in the Blackwater National Wildlife Refuge have been lost since the 1930s, and estimates of loss today range 50-150 ha year ${ }^{-1}$ (Cahoon, Guntenspergen \& Baird 2010).

\section{EXPERIMENTAL METHODS}

We constructed three platforms containing mesocosms at different elevations to simulate the response of plant growth to different flooding regimes (Fig. 1). The experimental design is modelled after experiments referred to as 'marsh organs' that manipulate elevations at a single point in an attempt to isolate the effect of hydroperiod from other variables (e.g. salinity and substrate composition) that would covary along a transect across a natural elevation gradient (Morris 2007; Mudd, Howell \& Morris 2009; Voss 2009). Therefore, our approach facilitates a relatively quick assessment of the response of plant growth to sea level rise where long-term records of productivity are not available (e.g. Morris et al. 2002; Kirwan et al. 2012). Each platform contained 36 mesocosms constructed of 6-inch-diameter $\left(182 \mathrm{~cm}^{2}\right)$ PVC pipe, arranged into six rows each containing six pipes of identical elevation. Pipe lengths varied between 45 and $80 \mathrm{~cm}$, so that each platform covered an elevation range of $35 \mathrm{~cm}$. The bottom of each pipe was buried approximately $5 \mathrm{~cm}$ into the native substrate and filled with sediment from the adjacent pond or creek bottom.

Two platforms were placed in small tidal creeks, and the third platform was placed in a shallow pond adjacent to the tidal creek, so that its elevation range extended well above the marsh surface. Together, the platforms covered an elevation range of between $-5 \mathrm{~cm}$ and $46 \mathrm{~cm}$ North American Vertical Datum (NAVD). Mean sea level at the site is approximately $0 \mathrm{~cm} \mathrm{NAVD}$, and the elevation of adjacent marshland is approximately 10-15 cm above NAVD (Hensel et al. 2008). As water level at the site is dominated by meteorological events rather than astronomical tides, calculations of row heights relative to tidal data (e.g. inundation depth at mean high tide) are not meaningful.

On 22-23 April 2010, we transplanted plugs of intact marsh sod approximately $15 \mathrm{~cm}$ long and $15 \mathrm{~cm}$ in diameter from nearby marsh into the top of each pipe. One channel-located platform was planted exclusively with $S$. patens, while the other channel platform was planted in S. americanus. Half of the pond platform was planted in S. patens and half planted with S. americanus. On May 20, we buried cylindrical nylon mesh bags filled with root-free commercial freshwater peat to a depth of $30 \mathrm{~cm}$ to measure the production of roots throughout the growing season (Gallagher, Wolf \& Pfieffer 1984; McKee, Cahoon \& Feller 2007; Langley \& Megonigal 2010). These 'ingrowth bags' were $30 \mathrm{~cm}$ long, $5 \mathrm{~cm}$ in diameter and placed randomly into half of the mesocosms. Sods and ingrowth bags were 

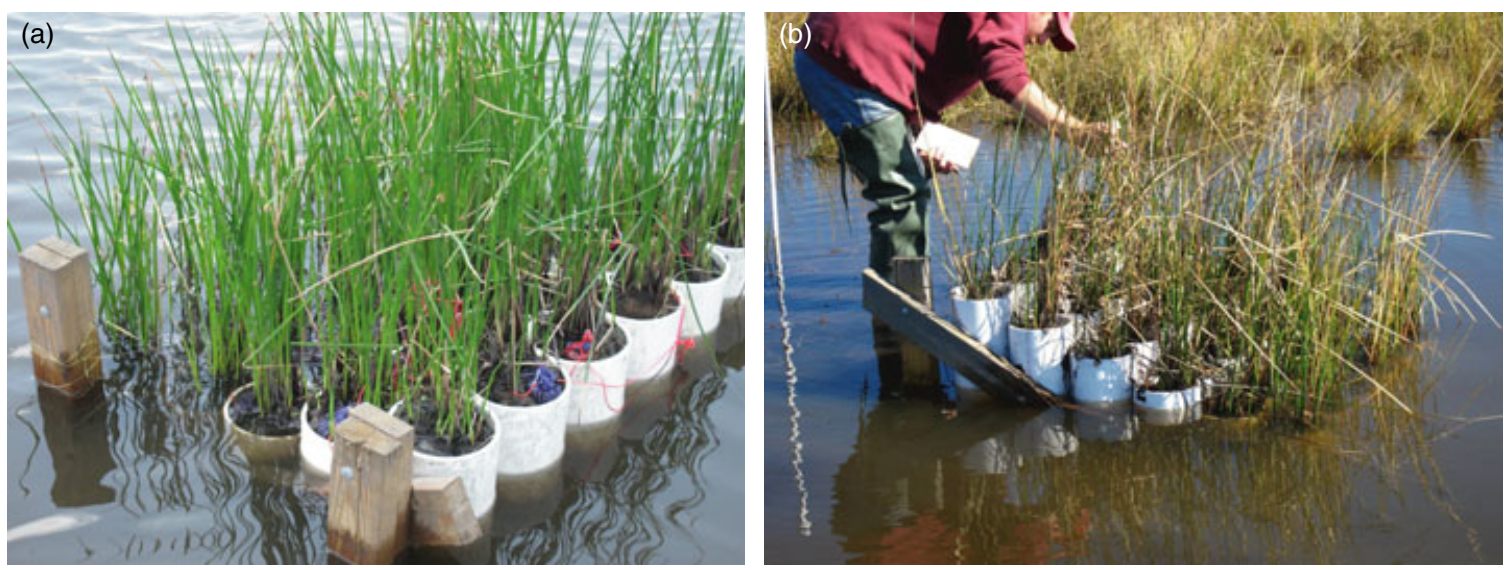

Fig. 1. Photographs of elevation platforms planted in Schoenoplectus americanus located in a small tidal creek (a) and an intertidal pond (b).

removed from the mesocosms at the end of the growing season and transported to the laboratory for analysis on 16 September 2010.

\section{LABORATORY METHODS}

Plant stems from each mesocosm were clipped at the bed surface to isolate standing above-ground material and sorted into live and dead fractions by species. We counted the total number of $S$. americanus stems and measured the length of the tallest five stems of each species. Above-ground biomass was washed and dried at $70{ }^{\circ} \mathrm{C}$ to a constant weight. Root material in ingrowth bags was rinsed to remove inorganic material and commercial peat, then sorted into three size fractions (rhizome, coarse roots and fine roots) and dried following similar methodology (Saunders, Megonigal \& Reynolds 2006). Finally, the total mass of all below-ground material (rhizomes, live and dead roots of all size) was estimated at one platform by harvesting the entire root mass and washing away any loose material.

\section{Results}

Both above-ground and below-ground components of $S$. americanus growth varied strongly as a function of meso-

(a)

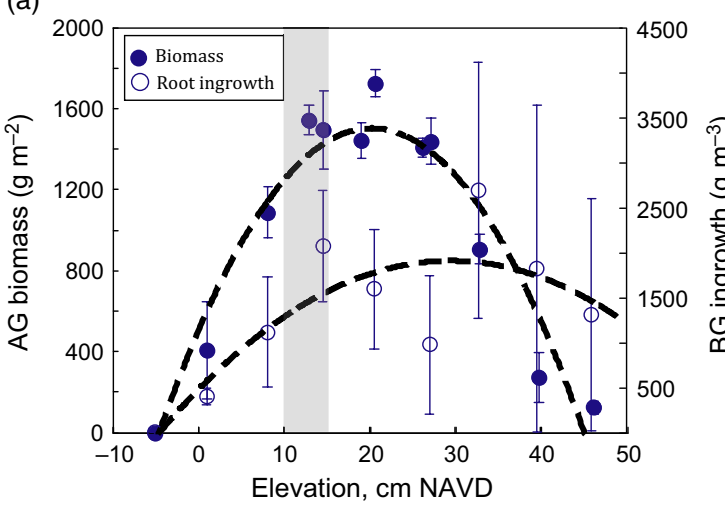

cosm elevation and its effect on inundation. The number of stems, stem height, shoot biomass and root ingrowth rates all followed a parabolic, hump-shaped relationship with elevation (Figs 2 and 3). Plant growth was minimal in the highest and lowest elevation rows, and maximum (1500 $\mathrm{g} \mathrm{m}^{-2}$ aboveground and $1900 \mathrm{~g} \mathrm{~m}^{-3}$ below-ground) at an elevation approximately $5-15 \mathrm{~cm}$ above the adjacent marsh surface. A quadratic fit $\left(r^{2}=0.92, P=0.000001\right)$ through the aboveground biomass data indicates that the minimum, maximum and optimum elevations for $S$. americanus at the site are $-5,45$ and $20 \mathrm{~cm}$ NAVD, respectively (Fig. 2a).

In contrast, $S$. patens showed no uniformity in its growth pattern over multiple elevations. Metrics of above-ground growth (i.e. stem length and, shoot biomass) increased with elevation across all rows, but metrics of below-ground growth followed a hump-shaped pattern with a distinct optimum elevation 15-20 cm above the adjacent marsh surface $\left(2500 \mathrm{~g} \mathrm{~m}^{-3}\right)$. A quadratic fit $\left(r^{2}=0.71 P=0.004\right)$ through the root ingrowth mass data indicates that the minimum, maximum and optimum elevations for $S$. patens at the site are 10 , 50 and $30 \mathrm{~cm}$ NAVD, respectively (Fig. 2b).

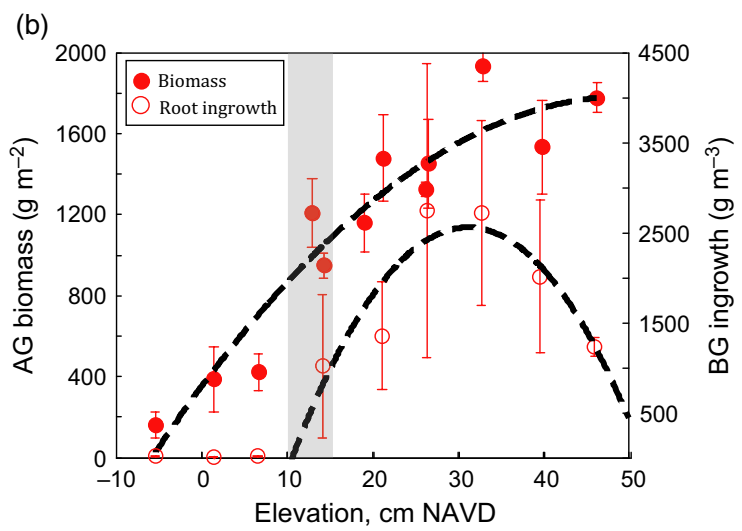

Fig. 2. Live above-ground biomass at the end of growing season (solid circles) and root production measured in ingrowth bags (open circles). Each marker represents the average biomass of six mesocosms with identical elevations, and error bars represent the standard error between the six mesocosms. Panel a represents mesocosms planted in Schoenoplectus americanus. Panel b represents mesocosms planted in Spartina patens. Dashed lines indicate best quadratic fits: $S$. americanus biomass $\left(y=-2.4 x^{2}+96.9 x+495.6, r^{2}=0.92, P<0.001\right)$, S. americanus root production $\left(y=-1.6 x^{2}+96.9 x+474.9, r^{2}=0.66, P=0.008\right)$, S. patens biomass $\left(y=-0.6 x^{2}+56 x+344.9, r^{2}=0.90 P<0.001\right)$, $S$. patens root production $\left(y=-6.0 x^{2}+375.7 x-3315.8, r^{2}=0.71 P=0.004\right)$. Grey shading denotes the approximate elevation of the adjacent marsh platform. 
(a)
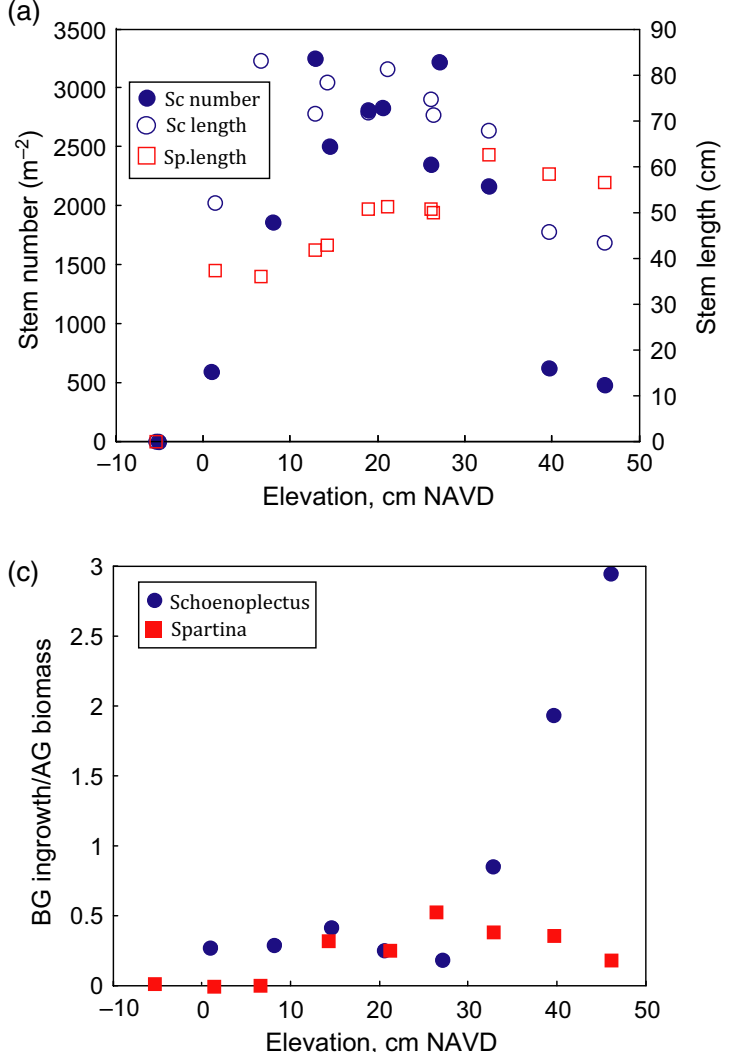

(b)

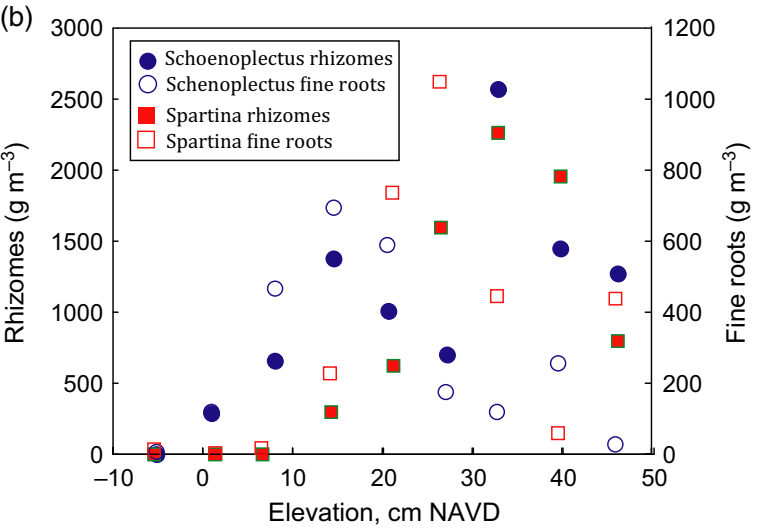

Fig. 3. (a) Number of stems and length of tallest five stems in each mesocosm. Number of Spartina patens stems were not counted. 'Sc' denotes Schoenoplectus americanus, and 'Sp' denotes Spartina patens. (b) Mass of rhizomes and fine roots measured in ingrowth bags. (c) Live root biomass measured in ingrowth bags $\left(\mathrm{g} \mathrm{m}^{-2}\right)$ divided by live above-ground biomass $\left(\mathrm{g} \mathrm{m}^{-2}\right)$, a proxy for root-to-shoot ratio.

\section{Discussion}

\section{ASSUMPTIONS AND JUSTIFICATION}

In this preliminary experiment designed to isolate the effect of inundation on the growth patterns of two important intertidal macrophytes, we have made several important assumptions. The most significant is that the design of the platform mesocosms at least approximates how plants will respond to rising sea levels and increasing periods of inundation. We recognize, for example, that drainage in a mesocosm surrounded by PVC pipe is likely to be different than in a natural marsh. Although vertical exchanges of water do dominate flow paths in natural marshes (Nuttle 1988), they are the only source of inundation and drainage in our experiments (i.e. no horizontal flow). Shading and its effect on soil temperature could also influence plant growth in the experiments. We oriented the elevation platforms, so that each row faced south to minimize shading effects and to ensure that each row received the same exposure to sunlight. Finally, the experiment does not directly consider changes in variables that may accompany sea level rise (e.g. salinity), because it was designed to isolate changes in inundation as the driving variable. Evapotranspiration, however, likely leads to a simultaneous increase in interstitial salinity with elevation that implicitly influences productivity in the experiment.

Nevertheless, patterns of above-ground growth in the mesocosms are consistent with well-established patterns between plant growth and elevation determined in field and laboratory experiments. For example, we observed that Schenoplectus americanus is more resilient to flooding than $S$. patens because $S$. americanus had a lower elevation for optimum growth and could survive growth at lower elevations. This pattern is consistent with the natural distribution of these species across elevation gradients, where $S$. patens commonly occupies higher elevations than S. americanus (Eleuterius 1972; Arp et al. 1993; Meert \& Hester 2010). Our findings are also consistent with manipulative experiments and long-term monitoring studies which demonstrate that above-ground S. patens growth rates decline more rapidly with progressive inundation than S. americanus (Broome, Mendelssohn \& McKee 1995; Gough \& Grace 1998; Erickson et al. 2007). Aerenchyma tissue is more developed in S. americanus than $S$. patens and helps alleviate waterlogging stress by delivering oxygen to roots in anaerobic soils (Burdick 1989; Arp et al. 1993; Lonard, Judd \& Stalter 2010). The compatibility between these mesocosm experiments and previous work suggests that our findings are not overly influenced by the experimental design 
and are relevant to understanding how sea level rise will effect plant growth in natural marshes.

\section{FEEDBACKS BETWEEN ROOT GROWTH AND INUNDATION}

Although above-ground relationships between marsh productivity and flooding are well studied, our experiments represent the first comprehensive effort to measure rates of root production in coastal wetlands as a function of inundation. An explicit understanding of below-ground response is important because indices of wetland health are rarely correlated with above-ground biomass (Nyman et al. 1994; Turner et al. 2004). Rather, root zone processes dominate the response of many marshes to sea level rise, especially where mineral sediment is limited (Turner, Swenson \& Milan 2000; Cahoon et al. 2006; Nyman et al. 2006). For example, changes in the elevation of $S$. patens marshes are commonly related to expansion or contraction of the root zone (Cahoon, Ford \& Hensel 2004), and elevated $\mathrm{CO}_{2}$ experiments demonstrate that enhanced root growth in S. americanus marshes can allow a submerging marsh to build elevation at rates similar to sea level rise (Langley et al. 2009). Spatial variability in the rate of elevation gain for organic rich marshes can be directly explained by variability in root production because decomposition rates are not strongly related to patterns of inundation in tidal marshes (Blum 1993). The limited role of inundation in influencing the decay of organic matter in wetland soils has been widely observed (Valiela et al. 1982, 1984; Bertness 1985; Hackney 1987; Blum 1993). Therefore, the hump-shaped response of root production to inundation that we measured is likely to be accompanied by a hump-shaped response in the rate of organic accretion and elevation change.

Our experimental results therefore imply a feedback between root growth and inundation that could help reconcile observations of stability in some systems with rapid submergence in others. At relatively high elevations, our mesocosm experiments demonstrate that an increase in the duration of flooding will promote enhanced root growth, and by inference, an increase in the rate of organic accretion. Thus, when elevations are above optimum, an increase in the rate of sea level rise will tend to be accompanied by an increase in vertical accretion in a manner that helps stabilize intertidal elevations. This mechanism is consistent with the strong coupling between peat accretion and sea level rise observed for millennia in sediment poor estuaries of New England (e.g. Redfield 1965). At relatively low elevations, however, our experiments demonstrate that an increase in flooding will lead to a decrease in root production and organic accretion. At these elevations, an increase in the rate of sea level rise leads to an unstable feedback where lower rates of accretion lead to more flooding and even further loss of root production, as has been proposed for marshes in coastal Louisiana (e.g. Nyman et al. 1993). The direction of feedback and its impact on marsh stability therefore depends on the elevation of the marsh within the intertidal zone. The novelty of our work lies in its ability to distinguish the biophys- (a)

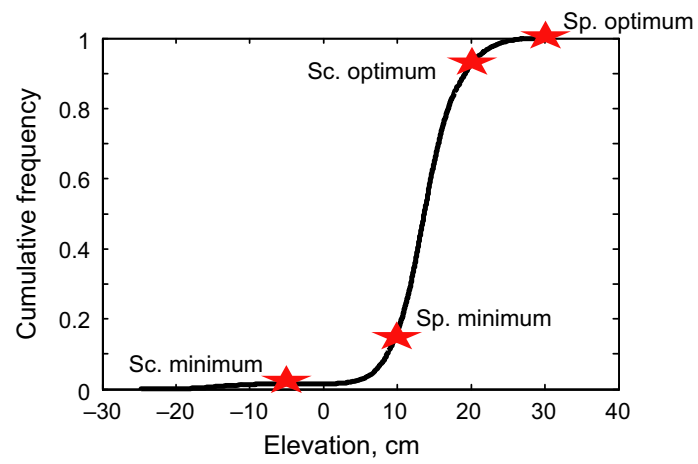

(b)

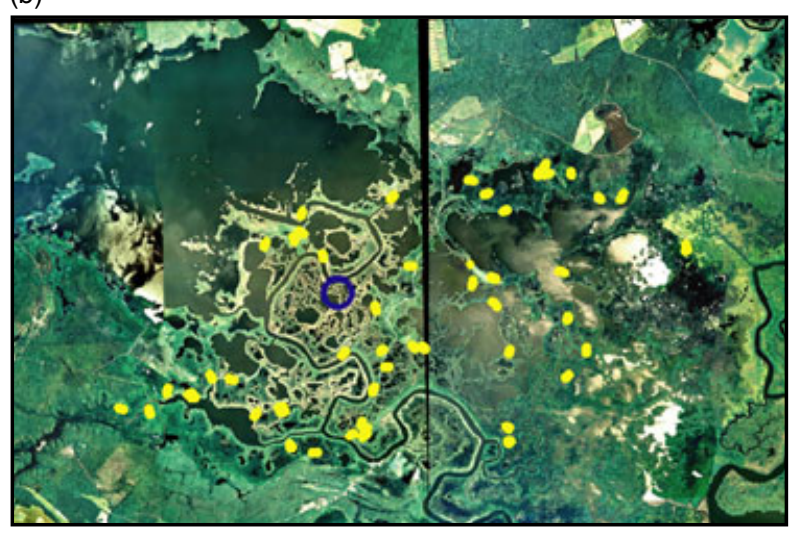

Fig. 4. (a) Cumulative frequency distribution of marsh elevations in the Blackwater National Wildlife Refuge relative to NAVD. Elevation data source is a 2010 US Fish and Wildlife Service real-time kinematic GPS survey with error of $\pm 15 \mathrm{~mm}$. For reference, $0 \mathrm{~cm}$ NAVD approximates mean sea level, and the elevation of the marsh adjacent to the experiments is $10-15 \mathrm{~cm}$ NAVD. Optimum and minimum elevations for plant growth (stars) are based on root production measurements in Fig. 3, except for the Schoenoplectus optimum that is based on above-ground production in Fig. 2. 'Sc' denotes Schoenoplectus americanus, and 'Sp' denotes Spartina patens. (b) Elevation measurements $(n=7233)$ were on vegetated marsh surfaces along 51 transects (light grey (yellow online) dots) in a $25-\mathrm{km}^{2}$ area. The location of the mesocosm experiments is outlined by the dark grey (blue online) ring. Photograph source: US Department of Agriculture.

ical conditions (i.e. elevation) at which these feedbacks are likely to switch direction.

In some cases, the behaviour resulting from below-ground feedbacks could resemble that described for strictly aboveground processes. For example, a positive relationship between inundation, above-ground growth and mineral deposition is thought to stabilize the response of high elevation S. alterniflora marshes to sea level rise (Morris et al. 2002; Kirwan et al. 2010; Fagherazzi et al. 2012). The main difference is that our results indicate a positive relationship between flooding and above-ground productivity holds for a portion of the growth range of $S$. americanus, but not for S. patens, suggesting that above-ground feedbacks are species dependent. Conversely, a hump-shaped response of below-ground productivity to flooding was consistent between both species. Therefore, our work suggests that a positive relationship between accretion and sea level rise (e.g. Friedrichs \& Perry 2001; Morris et al. 2002; Marion, Anthony \& Trentesaux 2009) cannot be explained by patterns of above-ground plant 
growth and mineral sediment deposition in all species. Instead, we offer an alternative, purely biological explanation (i.e. root growth and organic matter accumulation) that does not depend on mineral sediment availability. As the studied macrophytes utilize different photosynthetic pathways ( $S$. americanus, $\mathrm{C}_{3} ; \mathrm{S}$. patens, $\mathrm{C}_{4}$ ) and occur at different elevations within the intertidal zone ( $S$. americanus, near MSL, S. patens, near MHT), our results suggest that the feedbacks described for S. alterniflora marshes could be more widely applicable than previously known, but for fundamentally different reasons.

Elevation surveys in our study site indicate that a runaway feedback between inundation and reduced root production may already be occurring. Out of more than 70000 points surveyed in the Blackwater National Wildlife Refuge that are covered by marsh vegetation, more than $80 \%$ are below the optimum elevation for $S$. americanus root production, and virtually all ( $>99 \%$ ) are below the optimum elevation for $S$. patens (Fig. 4). Local measurements of vertical accretion and elevation change are less than rates of sea level rise, indicating that these marshes are losing elevation relative to sea level (Stevenson, Kearney \& Pendleton 1985; Cahoon, Guntenspergen $\&$ Baird 2010). Although a loss of elevation can be accompanied by faster root production and/or mineral accretion in marshes at relatively high elevations, our experiments indicate that elevations here are already too low and that root production will continue to decline with further sea level rise. Therefore, the mesocosm experiments coupled with the elevation survey suggest that these marshes are following an unstable trajectory where loss of wetland elevation leads to lower rates of organic accretion and even greater rates of marsh submergence. We propose that this unstable feedback is largely responsible for the rapid rates of marsh loss in our study region and perhaps for rapid rates of marsh loss in other sediment deficient regions (e.g. Louisiana, Venice Lagoon).

\section{Acknowledgements}

We appreciate the contributions of Patrick Brennand and Kyle Derby in the field and laboratory. The US Geological Survey Global Change Research Program supported MLK and GRG.

\section{References}

Allen, J.R.L. (2000) Morphodynamics of Holocene salt marshes: a review sketch from the Atlantic and southern North Sea coasts of Europe. Quaternary Science Reviews, 19, 1155-1231.

Arp, W.J., Drake, B.G., Pockman, W.T., Curtis, P.S. \& Whigham, D.F. (1993) Interactions between $\mathrm{C} 3$ and $\mathrm{C} 4$ salt marsh plant species during four years exposure to elevated atmospheric $\mathrm{CO}_{2}$. Vegetatio, 104/105, 133-143.

Bertness, M.D. (1985) Fiddler crab regulation of Spartina alterniflora production in a New England salt marsh. Ecology, 66, 1042-1055.

Blum, L.K. (1993) Spartina alterniflora root dynamics in a Virginia Marsh. Marine Ecology Progress Series, 102, 169-178.

Broome, S.W., Mendelssohn, I.A. \& McKee, K.L. (1995) Relative growth of Spartina patens (Ait.) Muhl. And Scirpus olneyi gray occurring in a mixed stand as affected by salinity and flooding depth. Wetlands, 15, 20-30.

Burdick, D.M. (1989) Root aerenchyma development in Spartina patens in response to flooding. American Journal of Botany, 76, 777-780.

Cahoon, D.R., Ford, M.A. \& Hensel, P.F. (2004) Ecogeomorphology of Spartina patens-dominated tidal marshes: soil organic matter accumulation, marsh elevation dynamics, and disturbance. The Ecogeomorphology of Tidal Marshes, Coastal and Estuarine Studies, Vol. 59 (eds S. Fagherazzi,
M. Marani \& L.K. Blum), pp. 247-266. American Geophysical Union, Washington, DC, USA.

Cahoon, D.R., Guntenspergen, G.R. \& Baird, S. (2010) Do annual prescribed fires enhance or slow the loss of coastal marsh habitat at Blackwater National Wildlife Refuge? Final Report to Joint Fire Science Program, http://www.firescience.gov/projects/06-2-1-35/project/06-2-1-35_blackwater_ burn_final_report_mar_31_2010.pdf.

Cahoon, D.R., Hensel, P.F., Spencer, T., Reed, D.J., McKee, K.L. \& Saintilan, N. (2006) Coastal wetland vulnerability to relative sea-level rise: wetland elevation trends and process controls. Wetlands and Natural Resource Management: Ecological Studies, Vol. 190 (eds J.T. A Verhoeven, B. Beltman, R. Bobbink \& D.F. Whigham), pp. 271-292. Springer, Berlin.

D'Alpaos, A., Lanzoni, S., Mudd, S.M. \& Fagherazzi, S. (2006) Modeling the influence of hydroperiod and vegetation on the cross-sectional formation of tidal channels. Estuarine, Coastal and Shelf Science, 69, 311-324.

D'Alpaos, A., Lanzoni, S., Marani, M. \& Rinaldo, A. (2007) Landscape evolution in tidal embayments: modeling the interplay of erosion, sedimentation, and vegetation dynamics. Journal of Geophysical Research, 112, F01008.

Day, J., Ibanez, C., Scarton, F., Pont, D., Hensel, P., Day, J. \& Lane, R. (2011) Sustainability of Mediterranean deltaic and lagoon wetlands with sea-level rise: the importance of river input. Estuaries and Coasts, 34, 483-493.

Eleuterius, L.N. (1972) The marshes of Mississippi. Castanea, 37, 153-168.

Erickson, J.E., Megonigal, J.P., Peresta, G. \& Drake, B.G. (2007) Salinity and sea level mediate elevated $\mathrm{CO}_{2}$ effects on $\mathrm{C} 3-\mathrm{C} 4$ plant interactions and tissue nitrogen in a Chesapeake Bay tidal wetland. Global Change Biology, 13, 202 215.

Fagherazzi, S., Kirwan, M.L., Mudd, S.M., Guntenspergen, G.R., Temmerman, S., D'Alpaos, A. et al. (2012) Numerical models of salt marsh evolution: ecological, geomorphic, and climatic factors. Reviews of Geophysics, 50, RG1002.

Friedrichs, C.T. \& Perry, J.E. (2001) Tidal salt marsh morphodynamics: a synthesis. Journal of Coastal Research, 27, 7-37.

Gallagher, J.L., Wolf, P.L. \& Pfieffer, W.J. (1984) Rhizome and root growth rates and cycles in protein and carbohydrate concentrations in Georgia Spartina alterniflora Loisel. Plants. American Journal of Botany, 71, 165169.

Gough, L. \& Grace, J.B. (1998) Effects of flooding, salinity and herbivory on coastal plant communities, Louisiana, United States. Oecologia, 117, 527535 .

Hackney, C.T. (1987) Factors affecting accumulation or loss of macroorganic matter in salt marsh sediments. Ecology, 68, 1109-1113.

Hensel, P.F., Scott, G.A., Allen, A.L., Gill, S.K., Cahoon, D.R., Nemerson, D. \& Guntenspergen, G.R. (2008) Geodetic and tidal datums: tying wetland surface elevation change to local water levels. 2008 Ocean Sciences Meeting Abstract. American Geophysical Union, Orlando, FL, USA.

Kirwan, M.L. \& Guntenspergen, G.R. (2010) The influence of tidal range on the stability of coastal marshland. Journal of Geophysical Research - Earth Surface, 115, F02009.

Kirwan, M.L. \& Murray, A.B. (2007) A coupled geomorphic and ecological model of tidal marsh evolution. Proceedings of the National Academy of Sciences, 104, 6118-6122.

Kirwan, M.L., Guntenspergen, G.R., D’Alpaos, A., Morris, J.T., Mudd, S.M. \& Temmerman, S. (2010) Limits on the adaptability of coastal marshes to rising sea level. Geophysical Research Letters, 37, L23401.

Kirwan, M.L., Murray, A.B., Donnelly, J.P. \& Corbett, D.R. (2011) Rapid wetland expansion during European settlement and its implication for marsh survival under modern sediment delivery rates. Geology, 39, 507-510.

Kirwan, M.L., Christian, R.R., Blum, L.K. \& Brinson, M.M. (2012) On the relationship between sea level and Spartina alterniflora production. Ecosystems, doi: 10.1007/s10021-011-9498-7.

Langley, J.A. \& Megonigal, J.P. (2010) Ecosystem response to elevated $\mathrm{CO}_{2}$ levels limited by nitrogen-induced plant species shift. Nature, 466, 96-99.

Langley, J.A., Mckee, K.L., Cahoon, D.R., Cherry, J.A. \& Megonigal, J.P. (2009) Elevated $\mathrm{CO}_{2}$ stimulates marsh elevation gain, counterbalancing sealevel rise. Proceedings of the National Academy of Sciences, 106, 6182-6186.

Lonard, R.I., Judd, F.W. \& Stalter, R. (2010) The biological flora of coastal dunes and wetlands: Spartina patens (W. Aiton) G.H. Muhlenberg. Journal of Coastal Research, 26, 935-946.

Lorenzo-Trueba, J., Voller, V.R., Paola, C. \& Twilley, R.R. (2010) Toward a model framework for sedimentary delta growth that accounts for biological processes. Abstract B33D-0427. AGU Fall Meeting, San Francisco, CA, USA. 
Marani, M., Lanzoni, S., Silvestri, S. \& Rinaldo, A. (2004) Tidal landforms, patterns of halophytic vegetation and the fate of the lagoon of Venice. Journal of Marine Systems, 51, 191-210.

Marani, M., D'Alpaos, A., Lanzoni, S., Carniello, L. \& Rinaldo, A. (2007) Biologically-controlled multiple equilibria of tidal landforms and the fate of the Venice lagoon. Geophysical Research Letters, 34, L11402.

Marion, C., Anthony, E.J. \& Trentesaux, A. (2009) Short-term ( $<=2$ yrs) estuarine mudflat and saltmarsh sedimentation: high-resolution data from ultrasonic altimetery, rod surface-elevation table, and filter traps. Estuarine, Coastal and Shelf Science, 83, 475-484.

Mariotti, G. \& Fagherazzi, S. (2010) A numerical model for the coupled longterm evolution of salt marshes and tidal flats. Journal of Geophysical Research, 115, F01004

McKee, K.L., Cahoon, D.R. \& Feller, I.C. (2007) Caribbean mangroves adjust to rising sea level through biotic controls on change in soil elevation. Global Ecology and Biogeography, 16, 545-556.

Meert, D.R. \& Hester, M.W. (2010) Response of a Louisiana oligohaline marsh plant community to nutrient availability and disturbance. Journal of Coastal Research, Special Issue 54, 174-185.

Morris, J.T. (2007) Estimating net primary production of salt-marsh macrophytes. Principles and Standards for Measuring Primary Production (eds (T.J. Fahey \& A.K. Knapp), pp. 106-119. Oxford University Press, New York.

Morris, J.T. \& Haskins, B. (1990) A 5-yr record of aerial primary production and stand characteristics of Spartina alterniflora. Ecology, 71, 2209-2217.

Morris, J.T., Sundareshwar, P.V., Nietch, C.T., Kjerfve, B. \& Cahoon, D.R. (2002) Responses of coastal wetlands to rising sea level. Ecology, 83, 28692877.

Mudd, S.M., D'Alpaos, A. \& Morris, J.T. (2010) How does vegetation affect sedimentation on tidal marshes? Investigating particle capture and hydrodynamic controls on biologically mediated sedimentation. Journal of Geophysical Research, 115, F03029.

Mudd, S.M., Howell, S.M. \& Morris, J.T. (2009) Impact of dynamic feedbacks between sedimentation, sea-level rise, and biomass production on near surface marsh stratigraphy and carbon accumulation. Estuarine, Coastal and Shelf Science, 82, 377-389.

Mudd, S.M., Fagherazzi, S., Morris, J.T. \& Furbish, D.J. (2004) Flow, sedimentation, and biomass production on a vegetated salt marsh in South Carolina: toward a predictive model of marsh morphologic and ecologic evolution. The Ecogeomorphology of Tidal Marshes (eds S. Fagherazzi, A. Marani \& L.K. Blum), pp. 165-187. Coastal and Estuarine Monograph Series. American Geophysical Union, Washington, DC, USA.

Nuttle, W.K. (1988) The extent of lateral water movement in the sediments of a New England salt marsh. Water Resources Research, 24, 2077-2085.

Nyman, J.A., DeLaune, R.D., Roberts, H.H. \& Patrick Jr, W.H. (1993) Relationship between vegetation and soil formation in a rapidly submerging coastal marsh. Marine Ecology Progress Series, 96, 269-279.
Nyman, J.A., Carloss, M., DeLaune, R.D. \& Patrick Jr, W.H. (1994) Erosion rather than plant dieback as the mechanism of marsh loss in an estuarine marsh. Earth Surface Processes and Landforms, 19, 69-84.

Nyman, J.A., Walters, R.J., Delaune, R.D. \& Patrick, W.H. (2006) Marsh vertical accretion via vegetative growth. Estuarine, Coastal and Shelf Science, 69, 370-380.

Redfield, A.C. (1965) Ontogeny of a salt marsh estuary. Science, 147, 50-55.

Reed, D.J. (1995) The response of coastal marshes to sea-level rise: survival or submergence? Earth Surface Processes and Landforms, 20, 39-48.

Saunders, C.J., Megonigal, J.P. \& Reynolds, J.F. (2006) Comparison of belowground biomass in C3- and C4-dominated mixed communities in a Chesapeake Bay brackish marsh. Plant and Soil, 280, 305-322.

Stevenson, J.C., Kearney, M.S. \& Pendleton, E.C. (1985) Sedimentation and erosion in a Chesapeake Bay brackish marsh system. Marine Geology, 67, 212-235.

Syvitsky, J.P.M., Kettner, A.J., Overeem, I., Hutton, E.W.H., Hannon, M.T., Brakenridge, G.R., Day, J., Vorosmarty, C., Saito, Y., Giosan, L. \& Nicho1ls, R.J. (2009) Sinking deltas due to human activities. Nature Geoscience, 2, 681-686.

Teal, J.M. \& Howes, B.L. (1996) Interannual variability of a saltmarsh ecosystem. Limnology and Oceanography., 41, 802-809.

Turner, R.E., Swenson, E.M. \& Milan, C.S. (2000) Organic and inorganic contributions to vertical accretion in salt marsh sediments. Concepts and Controversies in Tidal Marsh Ecology (eds M.P. Weinstein \& D.A. Kreeger), pp. 583-595. Kluwer Academic Press, Dordrecht, The Netherlands.

Turner, R.E., Swenson, E.M., Milan, C.S., Lee, J.M. \& Oswald, T.A. (2004) Below-ground biomass in healthy and impaired salt marshes. Ecological Research, 19, 29-35.

Valiela, I., Howes, B., Howarth, R., Giblin, A., Foreman, K., Teal, J. \& Hobbie, J. (1982) The regulation of primary production and decomposition in a salt marsh ecosystem. Wetlands: Ecology and Management (eds B. Gopal, R.E. Turner, R.G. Wetzel \& D.E. Whigham), pp. 151-168. Nat. Inst. Of Ecology, Jaipur, India.

Valiela, I., Wilson, J., Buchsbaum, R., Rietsma, C., Bryant, D., Foreman, K. \& Teal, J. (1984) Importance of chemical composition of salt marsh litter on decay rates and feeding by detritivores. Bulletin of Marine Science, 35, 261269.

Visser, J.M., Sasser, C.E. \& Cade, B.S. (2006) The effect of multiple stressors on salt marsh end-of-season biomass. Estuaries and Coasts, 29, 328-339.

Voss, C.M. (2009) Responses of dominant marsh macrophytes to inundation and disturbance and assessing marsh ecosystem services. MS thesis, East Carolina University, Greenville, NC, USA, 251 pp.

Walling, D.E. \& Fang, D. (2003) Recent trends in the suspended sediment loads of the world's rivers. Global and Planetary Change, 39, 111-126.

Received 13 October 2011; accepted 12 January 2012

Handling Editor: John Lee 